\title{
Plant Diversity and Vegetation Structures in the Understory of Mixed Boreal Forests under Different Management Regimes
}

\author{
Wen Wu ${ }^{1,2}$, Yuanman Hu${ }^{1}$, Yuehui Li ${ }^{1 *}$, Jiping Gong ${ }^{1,2}$, \\ Long Chen ${ }^{1,2}$, Yu Chang ${ }^{1}$, Zaiping Xiong ${ }^{1}$ \\ ${ }^{1}$ Key Laboratory of Forest Ecology and Management, Institute of Applied Ecology, Chinese Academy of Sciences, \\ Shenyang 110164, People's Republic of China \\ ${ }^{2}$ University of Chinese Academy of Sciences, Beijing 100049, People's Republic of China
}

Received: 30 September 2015

Accepted: 7 March 2016

\begin{abstract}
Community surveys were performed in 30 forest stands with similar conditions under different management types in forests of northeastern China to study the influence of forest management on plant biodiversity. We evaluated this effect by calculating and analyzing species richness, vegetation structure, and aboveground biomass. Large variations in species composition, vegetation structure, species richness, and aboveground biomass were evident among the three types of common management types investigated (cut shrub tending, selective cutting, and understory planting). The species composition of the herb layer changed more than that of the shrub layer, and herbs were more vulnerable to impact from human activities. Each management type reduced the plant coverage, and this was most significant in planted plots. We found that in the cut shrub tending plots, the shrub height increased over time. The mean fresh weight of the control group was about $2 \mathrm{~kg} \cdot \mathrm{m}^{-2}$, which was about two-fold the selective cutting group $\left(1 \mathrm{~kg} \cdot \mathrm{m}^{-2}\right)$ and five-fold the understory planting group $\left(0.4 \mathrm{~kg} \cdot \mathrm{m}^{-2}\right)$. Our results also showed that management types in mixed forest stands strongly impact species diversity and, to some extent, environmental capacity, with negative effects on biodiversity.
\end{abstract}

Keywords: biodiversity conservation, biomass, species richness, forest management, northeastern China

\section{Introduction}

Researchers have extensively studied the effects of human disturbance, such as logging operations, on species richness. Typically the theme is the tree layer, and little is known about understory vegetation [1-4]. But in fact,

*e-mail: liyh@iae.ac.cn understory species accounted for more than $90 \%$ of the richness in temperate forest vegetation $[5,6]$, which was the main component of vegetation species diversity in this ecosystem. Although understory biomass is smaller than overstory biomass, the aboveground part of net primary productivity (ANPP) from understory biomass was more than half of the ANPP of the forest canopy in boreal forest vegetation [7]. Therefore, understory vegetation plays an important role in maintaining forest ecosystem structure and function [8]. 
The existence of complex species composition and stand structure can reflect the sustainability of forest management [9], and different management styles often lead to differences in community structure and biodiversity $[10,11]$. Forest management operations such as logging, tending, planting, and picking (e.g., fruits of Chinese magnolia vine and blueberries) have seldom been studied comprehensively in China, and various forest management types have not been compared. But in fact, the complex influence of different management systems needs to be studied [12-15]. Furthermore, they constitute a "management system" and reflect human activities related to the use of forest resources $[1,16]$. For example, species richness and the Simpson index decreased as the frequency of plantation increased [17]. And clear-cutting is a controversial forest management practice in terms of its effect on forest ecology. Therefore, it is of interest to investigate the impacts of different management regimes on the diversity of the forest structure and on forest carbon storage [18].

In general, studies related to forest management are focused on the intensity of management and less attention has been paid to management types. Management directly or indirectly affects plant biodiversity and stand structure in the understory by negatively influencing species richness and modifying diversity $[1,10]$. In addition, this management of human activities often threatens plant biodiversity and animal habitat [19-22]. Herve and Vidal (2008) had shown that a moderate level of management (i.e., less than $30 \%$ of the selective felling) improved community species diversity while intense management had the opposite effect. Studies indicate that thinning and felling had no significant effect on long-term species diversity [23-24], but planting had a significant negative impact on shrub species diversity. Management designed to mimic nature results in increased diversity when compared with more intense management, which may be associated with specific conditions at particular sites and different management-type areas [25]. In summary, the effect of different management regimes on species composition, community structure, and plant diversity of forests is difficult to be quantitatively compared.

We chose forest stands with similar conditions in the tree layer and found sites with different types of treatment occurring only in the understory [26]. We know that the influence of different management measures are different regarding species composition, community structure, and plant biodiversity in the understory of broadleaved mixed forests. We try to quantify and evaluate this influence by calculating species biodiversity, community structure characteristics, and aboveground biomass in northeastern China.

\section{Study Area and Methods}

\section{Study Area}

The Tieli forestry bureau (TFB) in northeastern China, with study areas located at $46^{\circ} 55^{\prime}-47^{\circ} 36^{\prime} \mathrm{N}$, $127^{\circ} 57^{\prime}-128^{\circ} 42^{\prime} \mathrm{E}$ and elevations ranging from 225 to $1148 \mathrm{~m}$ a.s.l., contained the sites for our field investigations. The mean annual temperature is about $2^{\circ} \mathrm{C}$, and the highest temperature $\left(20^{\circ} \mathrm{C}\right)$ commonly appears in July. About $600 \mathrm{~mm}$ of rain falls each year on the mainly dark brown soils; small amounts of meadow, swamp, and peat soils are also present. The typical region's broadleaved mixed forests supports more than a hundred species of wild animals.

Many non-forestry land transformations have occurred in the southern TFB areas over the last 30 years, and forests consisted of fragments of agricultural or urbanized matrixes. Long-term and excessive cutting has significantly reduced the extent of forested lands [27, 28], but fortunately, timber harvesting was halted and the forest was protected and allowed to recover. After 2000, five forestry bureaus (including Tieli forestry bureau of Yichun, China) have initiated state-owned forest tenure reform. This system involved the selection of $80,000 \mathrm{hm}^{2}$ of commercial forests from a total area of $785,000 \mathrm{hm}^{2}$, for management using 50-year contracts with individuals who are designated land managers at specific sites. Forest workers usually cultivate agaric (Auricularia auricula) or ginseng (Panax ginseng) at these sites. And during the growing season, diverse management techniques were usually implemented in understory planting sites, such as weeding, fertilizing, pruning, and harvesting. This policy improved the enthusiasm of local foresters and enriched the management pattern of understory planting, but at the same time increased the human disturbance of the understory layer, which generated the need for quantitative study.

\section{Sampling}

The field investigation was conducted in July, August, and September of 2013 in 30 forest stands with similar natural conditions in mixed forests in the TFB of the Lesser Xing'an Mountains. We selected eight sites within four forest management types: cut shrub tending (CT, two sites), selective cutting ( $\mathrm{SC}$, four sites), understory planting (UP, one site), and control group (CG, one site). Vegetation investigations were determined using three replicates of $400 \mathrm{~m}^{2}$ plots $(20 \mathrm{~m} \times 20 \mathrm{~m})$ at each site (treatment group), and nine repeated plots in the control group, totaling 30 plots. Tables 1 and 2 provide baseline data for each site. We investigated shrub species in three $2 \mathrm{~m} \times 2 \mathrm{~m}$ plots and herb species in three $1 \mathrm{~m} \times 1 \mathrm{~m}$ herb plots, per $400 \mathrm{~m}^{2}$ plot. Within each plot, we recorded several parameters for shrubs and herbs (i.e., species names, mean height, abundance, and coverage). A total of 17 shrub species and 24 herb species were found during surveys of the understory. We regarded tree seedlings as shrub species for plants less than $1 \mathrm{~m}$ tall. Abundance stands for the number of plants were classified into five grades: 1, 2, 3, 4 and 5, from small to large. A minimum distance of $200 \mathrm{~m}$ was maintained between any two of these plots. 
Table 1. Location information of plots at different sites.

\begin{tabular}{|c|c|c|c|}
\hline Treatment & Description & Sites & Geographic location \\
\hline \multirow{2}{*}{$\begin{array}{l}\text { Cut-shrub tending } \\
\qquad(\mathrm{CT})\end{array}$} & \multirow{2}{*}{$\begin{array}{l}\text { Tending by the cutting of shrubs, usually during } \\
\text { winter and near roads, one each operation in } 2010 \\
\text { and } 2012 .\end{array}$} & CT-2012 & $\begin{array}{l}\text { Plot } 1.47^{\circ} 09^{\prime} 09^{\prime \prime} \mathrm{N} 128^{\circ} 19^{\prime} 27^{\prime \prime} \mathrm{E} \\
\text { Plot 2. } 47^{\circ} 09^{\prime} 07^{\prime \prime} \mathrm{N} 128^{\circ} 19^{\prime} 25^{\prime \prime} \mathrm{E} \\
\text { Plot 3. } 47^{\circ} 09^{\prime} 06^{\prime \prime} \mathrm{N} 128^{\circ} 19^{\prime} 24^{\prime \prime} \mathrm{E}\end{array}$ \\
\hline & & CT-2010 & $\begin{array}{l}\text { Plot } 1.47^{\circ} 10^{\prime} 06^{\prime \prime} \mathrm{N} 128^{\circ} 15^{\prime} 12^{\prime \prime} \mathrm{E} \\
\text { Plot 2. } 47^{\circ} 10^{\prime} 07^{\prime \prime} \mathrm{N} 128^{\circ} 15^{\prime} 10^{\prime \prime} \mathrm{E} \\
\text { Plot 3. } 47^{\circ} 10^{\prime} 06^{\prime \prime} \mathrm{N} 128^{\circ} 15^{\prime} 13^{\prime \prime} \mathrm{E}\end{array}$ \\
\hline \multirow{4}{*}{$\begin{array}{l}\text { Selective cutting } \\
\text { (SC) }\end{array}$} & \multirow{4}{*}{$\begin{array}{l}\text { Selective cutting of } 30 \% \text { of the shrub layer, one each } \\
\text { operation in } 1998,2002,2007 \text {, and } 2013 .\end{array}$} & SC-2013 & $\begin{array}{l}\text { Plot } 1.47^{\circ} 05^{\prime} 09^{\prime \prime} \mathrm{N} 128^{\circ} 19^{\prime} 50^{\prime \prime} \mathrm{E} \\
\text { Plot 2. } 47^{\circ} 05^{\prime} 09^{\prime \prime} \mathrm{N} 128^{\circ} 19^{\prime} 48^{\prime \prime} \mathrm{E} \\
\text { Plot 3. } 47^{\circ} 05^{\prime} 10^{\prime \prime} \mathrm{N} 128^{\circ} 19^{\prime} 46^{\prime \prime} \mathrm{E}\end{array}$ \\
\hline & & SC-2007 & $\begin{array}{l}\text { Plot } 1.47^{\circ} 05^{\prime} 33^{\prime \prime} \mathrm{N} 128^{\circ} 22^{\prime} 02^{\prime \prime} \mathrm{E} \\
\text { Plot 2. } 47^{\circ} 05^{\prime} 34^{\prime \prime} \mathrm{N} 128^{\circ} 22^{\prime} 01^{\prime \prime} \mathrm{E} \\
\text { Plot 3. } 47^{\circ} 05^{\prime} 34^{\prime \prime} \mathrm{N} 128^{\circ} 22^{\prime} 00^{\prime \prime} \mathrm{E}\end{array}$ \\
\hline & & SC-2002 & $\begin{array}{l}\text { Plot } 1.47^{\circ} 05^{\prime} 38^{\prime \prime} \mathrm{N} 128^{\circ} 21^{\prime} 25^{\prime \prime} \mathrm{E} \\
\text { Plot 2. } 47^{\circ} 05^{\prime} 37^{\prime \prime} \mathrm{N} 128^{\circ} 21^{\prime} 25^{\prime \prime} \mathrm{E} \\
\text { Plot 3. } 47^{\circ} 05^{\prime} 37^{\prime \prime} \mathrm{N} 128^{\circ} 21^{\prime} 24^{\prime \prime} \mathrm{E}\end{array}$ \\
\hline & & SC-1998 & $\begin{array}{l}\text { Plot } 1.47^{\circ} 05^{\prime} 21^{\prime \prime} \mathrm{N} 128^{\circ} 19^{\prime} 31^{\prime \prime} \mathrm{E} \\
\text { Plot 2. } 47^{\circ} 05^{\prime} 25^{\prime \prime} \mathrm{N} 128^{\circ} 19^{\prime} 27^{\prime \prime} \mathrm{E} \\
\text { Plot 3. } 47^{\circ} 05^{\prime} 29^{\prime \prime} \mathrm{N} 128^{\circ} 19^{\prime} 26^{\prime \prime} \mathrm{E}\end{array}$ \\
\hline $\begin{array}{l}\text { Understory planting } \\
\text { (UP) }\end{array}$ & $\begin{array}{l}\text { Forest workers cultivate agaric or ginseng at these } \\
\text { sites, and the main crop species were not counted } \\
\text { when sampling. }\end{array}$ & UP & $\begin{array}{l}\text { Plot } 1.47^{\circ} 11^{\prime} 35^{\prime \prime} \mathrm{N} 128^{\circ} 23^{\prime} 17^{\prime \prime} \mathrm{E} \\
\text { Plot 2. } 47^{\circ} 11^{\prime} 34^{\prime \prime} \mathrm{N} 128^{\circ} 23^{\prime} 15^{\prime \prime} \mathrm{E} \\
\text { Plot 3. } 47^{\circ} 11^{\prime} 33^{\prime \prime} \mathrm{N} 128^{\circ} 18^{\prime} 36^{\prime \prime} \mathrm{E}\end{array}$ \\
\hline Control group (CG) & $\begin{array}{l}\text { Without any management, and mainly composed } \\
\text { of natural growth with little or no human or large } \\
\text { animal activity. }\end{array}$ & $\mathrm{CG}$ & $\begin{array}{l}\text { Plot 1. } 46^{\circ} 55^{\prime} 31^{\prime \prime} \mathrm{N} 128^{\circ} 11^{\prime} 07^{\prime \prime} \mathrm{E} \\
\text { Plot 2. } 46^{\circ} 55^{\prime} 29^{\prime \prime} \mathrm{N} 128^{\circ} 11^{\prime} 10^{\prime \prime} \mathrm{E} \\
\text { Plot 3. } 46^{\circ} 55^{\prime} 27^{\prime \prime} \mathrm{N} 128^{\circ} 11^{\prime} 09^{\prime \prime} \mathrm{E} \\
\text { Plot 4. } 47^{\circ} 35^{\prime} 28^{\prime \prime} \mathrm{N} 128^{\circ} 42^{\prime} 41^{\prime \prime} \mathrm{E} \\
\text { Plot 5. } 47^{\circ} 35^{\prime} 27^{\prime \prime} \mathrm{N} 128^{\circ} 42^{\prime} 33^{\prime \prime} \mathrm{E} \\
\text { Plot 6. } 47^{\circ} 35^{\prime} 26^{\prime \prime} \mathrm{N} 128^{\circ} 42^{\prime} 34^{\prime \prime} \mathrm{E} \\
\text { Plot 7. } 47^{\circ} 11^{\prime} 23^{\prime \prime} \mathrm{N} 128^{\circ} 32^{\prime} 50^{\prime \prime} \mathrm{E} \\
\text { Plot } 8.47^{\circ} 11^{\prime} 28^{\prime \prime} \mathrm{N} 128^{\circ} 32^{\prime} 10^{\prime \prime} \mathrm{E} \\
\text { Plot 9. } 47^{\circ} 11^{\prime} 20^{\prime \prime} \mathrm{N} 128^{\circ} 32^{\prime} 54^{\prime \prime} \mathrm{E}\end{array}$ \\
\hline
\end{tabular}

\section{Estimating Aboveground Biomass}

Shrub and herb aboveground biomass was calculated. We harvested the aboveground plants in each plot and measured their fresh weight. Then plant materials were dried to constant weight at $105^{\circ} \mathrm{C}$ in the lab and measured for dry weight. Finally, we calculated the biomass of shrub and herb layers per unit area.

Table 2. Summary of different forest stands at different sites.

\begin{tabular}{|c|c|c|c|c|c|c|c|c|}
\hline Sites & $\begin{array}{c}\text { Elevation }(\mathrm{m} \\
\text { a.s.1.) }\end{array}$ & Aspect & Slope $\left(^{\circ}\right)$ & $\begin{array}{c}\text { Canopy } \\
\text { density }\end{array}$ & Height $(\mathrm{m})$ & Age & Human & Animal \\
\hline CT-2012 & $250-288$ & West & $2-4$ & 0.8 & 8 & Half-mature & 3 & 1 \\
\hline CT-2010 & $288-294$ & North & $0-10$ & 0.6 & 12 & Half-mature & 3 & 1 \\
\hline SC-2013 & $356-406$ & West & $2-6$ & 0.4 & 11 & Near-mature & 2 & 2 \\
\hline SC-2007 & $422-433$ & Northeast & $5-10$ & 0.6 & 12 & Mature & 1 & 1 \\
\hline SC-2002 & $400-404$ & Northwest & $9-11$ & 0.4 & 9 & Near-mature & 1 & 0 \\
\hline SC-1998 & $293-390$ & West & $0-2$ & 0.6 & 14 & Mature & 2 & 2 \\
\hline UP & $296-308$ & West & $3-4$ & 0.5 & 14 & Mature & 3 & 1 \\
\hline CG & $256-276$ & None & $0-2$ & 0.8 & 15 & Mature & 0 & 0 \\
\hline
\end{tabular}

The intensity of human (Human) and animal (Animal) activities were classified by dividing them into four grades: $0,1,2$ and 3 , from weak to strong; CT, tending of cut shrubs; SC, selective cutting; UP, understory planting; CG, control group without treatment; year of management is also indicated for ST and SC sites. 
Table 3. Species composition of understory at different sites.

\begin{tabular}{|c|c|c|c|c|c|c|c|c|c|}
\hline & Latin name & CT-2012 & CT-2010 & SC-2013 & SC-2007 & SC-2002 & SC-1998 & UP & CG \\
\hline \multirow{24}{*}{ Herb } & Scirpus planiculmis & $\sqrt{ }$ & $\sqrt{ }$ & $\sqrt{ }$ & & & & $\sqrt{ }$ & $\sqrt{ }$ \\
\hline & Carex pilosa & $\sqrt{ }$ & $\sqrt{ }$ & $\sqrt{ }$ & $\sqrt{ }$ & $\sqrt{ }$ & $\sqrt{ }$ & $\sqrt{ }$ & $\sqrt{ }$ \\
\hline & Scopolia acutangula & $\sqrt{ }$ & & & & & $\sqrt{ }$ & & \\
\hline & Aegopodium alpestre & $\sqrt{ }$ & & $\sqrt{ }$ & $\sqrt{ }$ & $\sqrt{ }$ & $\sqrt{ }$ & $\sqrt{ }$ & $\sqrt{ }$ \\
\hline & Thalictrum aquilegifolium & $\sqrt{ }$ & & $\sqrt{ }$ & & $\sqrt{ }$ & & & $\sqrt{ }$ \\
\hline & Filipendula palmata & $\sqrt{ }$ & & $\sqrt{ }$ & $\sqrt{ }$ & $\sqrt{ }$ & $\sqrt{ }$ & $\sqrt{ }$ & $\sqrt{ }$ \\
\hline & Nettle & $\sqrt{ }$ & $\sqrt{ }$ & $\sqrt{ }$ & $\sqrt{ }$ & $\sqrt{ }$ & $\sqrt{ }$ & $\sqrt{ }$ & \\
\hline & Artemisia integrifolia & $\sqrt{ }$ & & & & & & & \\
\hline & Asarum sieboldii & $\sqrt{ }$ & & $\sqrt{ }$ & & $\sqrt{ }$ & & & $\sqrt{ }$ \\
\hline & Hippochaete hiemale & & $\sqrt{ }$ & $\sqrt{ }$ & $\sqrt{ }$ & $\sqrt{ }$ & & $\sqrt{ }$ & $\sqrt{ }$ \\
\hline & Heracleummoellendorffii & & $\sqrt{ }$ & & & & $\sqrt{ }$ & & $\sqrt{ }$ \\
\hline & Fragaria orientalis & & & & & $\sqrt{ }$ & & & \\
\hline & Syringa & & & & & $\sqrt{ }$ & & & \\
\hline & Cirsium japonicum & & & $\sqrt{ }$ & & & & & \\
\hline & Radix archangeliae decurrentis & & & $\sqrt{ }$ & & & $\sqrt{ }$ & & $\sqrt{ }$ \\
\hline & Deyeuxia langsdorffii & & & & & & & $\sqrt{ }$ & $\sqrt{ }$ \\
\hline & Polygonatum odoratum & & & & & & & & $\sqrt{ }$ \\
\hline & Equisetum pratense & & & & & & & & $\sqrt{ }$ \\
\hline & Humulus scandens & & & $\sqrt{ }$ & & & & & $\sqrt{ }$ \\
\hline & Actaea asiatica & & $\sqrt{ }$ & & & & & & $\sqrt{ }$ \\
\hline & Pisum sativum & & $\sqrt{ }$ & & & & & & $\sqrt{ }$ \\
\hline & Maianthemum bifolium & & & & & & & & $\sqrt{ }$ \\
\hline & Physialis peruviana & & & & $\sqrt{ }$ & & & & \\
\hline & Matteuccia struthiopteris & & $\sqrt{ }$ & & $\sqrt{ }$ & $\sqrt{ }$ & $\sqrt{ }$ & $\sqrt{ }$ & $\sqrt{ }$ \\
\hline \multirow{17}{*}{ Shrub } & Ulmus rubra & $\sqrt{ }$ & & & & & & & $\sqrt{ }$ \\
\hline & Tilia amurensis & $\sqrt{ }$ & & & & & $\sqrt{ }$ & & \\
\hline & Syringareticulata & $\sqrt{ }$ & $\sqrt{ }$ & $\sqrt{ }$ & $\sqrt{ }$ & $\sqrt{ }$ & $\sqrt{ }$ & $\sqrt{ }$ & \\
\hline & Acanthopanax senticosus & $\sqrt{ }$ & $\sqrt{ }$ & $\sqrt{ }$ & & & $\sqrt{ }$ & $\sqrt{ }$ & \\
\hline & Sorbaria sorbifolia & $\sqrt{ }$ & $\sqrt{ }$ & & & $\sqrt{ }$ & $\sqrt{ }$ & $\sqrt{ }$ & $\sqrt{ }$ \\
\hline & Corylus mandshurica & $\sqrt{ }$ & $\sqrt{ }$ & $\sqrt{ }$ & & $\sqrt{ }$ & $\sqrt{ }$ & & $\sqrt{ }$ \\
\hline & Syringa oblata & $\sqrt{ }$ & $\sqrt{ }$ & $\sqrt{ }$ & & $\sqrt{ }$ & & & \\
\hline & Schisandra chinensis & & $\sqrt{ }$ & $\sqrt{ }$ & & & & & \\
\hline & Fraxinus mandshurica & & $\sqrt{ }$ & $\sqrt{ }$ & & & & & \\
\hline & Juglans mandshurica & & $\sqrt{ }$ & & & & & & $\sqrt{ }$ \\
\hline & Rosa davurica & & $\sqrt{ }$ & $\sqrt{ }$ & & & & & \\
\hline & Salix babylonica & & & $\sqrt{ }$ & & & & & $\sqrt{ }$ \\
\hline & Populus suaveolens & & & & & & & & $\sqrt{ }$ \\
\hline & Lespedeza bicolor & & & & $\sqrt{ }$ & & & & $\sqrt{ }$ \\
\hline & Spiraea salicifolia & & $\sqrt{ }$ & & & & & & \\
\hline & Ulmus davidiana & & & & & & & & $\sqrt{ }$ \\
\hline & Lonicera japonica & & & $\sqrt{ }$ & $\sqrt{ }$ & $\sqrt{ }$ & $\sqrt{ }$ & & \\
\hline
\end{tabular}




\section{Estimation of Biodiversity and Statistical Analysis}

We used importance values $\left(p_{\mathrm{i}}\right)$ to represent the index of each species number to calculate the diversity indices. Diversity within and between plant communities was compared using diversity indices calculated for each community. Species richness $(S)$ was indicated by the total number of species in the community and by Shannon's diversity index $\left(H^{\prime}\right)$. Evenness and dominance were indicated by Pielou's diversity indices $(J)$ and BergerParker's index $(D)$. These indices were calculated using Equations (1) to (4):

Importance value $p_{\mathrm{i}}=$ (relative frequency + relative height + relative coverage) $/ 3$

$$
\begin{gathered}
J=\left(1-\sum_{i=1}^{s} p_{i}^{2}\right) /(1-1 / S) \\
H^{\prime}=-\sum_{i=1}^{s} p_{i} \ln p_{i} \\
D=1-\sum_{i=1}^{s} p_{i}^{2}
\end{gathered}
$$

We tested whether it shows difference of the biomass and diversity-value among forest management types. Data related to biomass and species richness $\left(S, J, H^{\prime}\right.$, and $D$ ) were analyzed by one-way ANOVA to compare the diversity within and between different sites.

\section{Results}

\section{Species Description}

Species sampled belonged to 23 plant families. The richest families were the Rosaceae (five species),
Oleaceae (four) and Umbelliferae (three). Double species represented each of nine families: the Cyperaceae, Solanaceae, Ranunculaceae, Ulmaceae, Salicaceae, Leguminosae, Liliaceae, Asteraceae, and Equisetaceae. Single species represented 11 families, accounting for half of the total number of species. Shrub species were dominated by Syringa reticulata and Scopolia acutangula in CT; Lonicera japonica, Corylus mandshurica, Sorbaria sorbifolia, and S. reticulata in SC; S. sorbifolia in UP, and Spiraea salicifolia and $S$. sorbifolia in CG. Herbaceous species were dominated by Carex pilosa and Aegopodium alpestre in CT; Hippochaete hiemale and C. pilosa in SC; Filipendula palmate, $H$. hiemale, and Deyeuxia langsdorffii in UP, and C. pilosa, Deyeuxia langsdorffii, and Polygonatum odoratum in CG (Table 3).

\section{Height and Coverage}

Table 4 summarizes the overall height and coverage of shrub and herbaceous plants in each site. Average height of the control group for shrub was lower than SC-2002 and SC-1998, whereas for herb it was lower than that of SC-2007 and CT-2010. Overall, understory planting decreased the height of shrub and herb plant communities: the herb layer grew well in cut-shrub tending sites, and shrubs were tall where selective cutting had been done for a longer period. We found that shrub height tended to increase in the selective cutting group while herb height decreased over time. The control group exhibited the highest average shrub and herb coverage. A significant difference $(p<0.05)$ was observed between different types of sites when analyzing shrub species and herbaceous species coverage and richness, respectively (Table 4). Finally, we found all management practices resulted in a lower shrub and herb layer coverage.

Table 4. Vegetation structure in the four different types of sites analyzed here.

\begin{tabular}{|c|c|c|c|c|c|c|}
\hline \multirow{2}{*}{ Sites } & \multicolumn{3}{|c|}{ Shrub species } & \multicolumn{3}{c|}{ Herbaceous species } \\
\cline { 2 - 7 } & Coverage (\%) & Abundance & Height $(\mathrm{cm})$ & Coverage (\%) & Abundance & Height (cm) \\
\hline CT-2012 & 7 & 1 & 53 & 39 & 3 & 28 \\
\hline CT-2010 & 22 & 3 & 73 & 71 & 5 & 39 \\
\hline SC-2013 & 17 & 2 & 87 & 61 & 4 & 31 \\
\hline SC-2007 & 22 & 3 & 109 & 60 & 4 & 38 \\
\hline SC-2002 & 41 & 4 & 123 & 40 & 3 & 30 \\
\hline SC-1998 & 39 & 3 & 163 & 49 & 3 & 24 \\
\hline UP & 6 & 1 & 17 & 33 & 2 & 27 \\
\hline CG & 46 & 4 & 111 & 87 & 5 & 37 \\
\hline$p$ & $*$ & $*$ & NS & $*$ & $*$ & NS \\
\hline
\end{tabular}

Abundance was classified into five grades: 1,2,3,4 and 5, from small to large; see Table 2 for definitions of acronyms. NS, not significant. Letters show significant differences between regions based on Tukey's post-hoc tests. ${ }^{*} p<0.05$. 


\section{Aboveground Biomass (AGB)}

A significant difference $(p<0.05)$ was observed between different types of sites when analyzing dry weights of herbs, with the cut shrub-tending 2010 group recording the highest AGB $\left(0.49 \mathrm{~kg} \cdot \mathrm{m}^{-2}\right)$ and the understory planting group recording the lowest AGB $\left(0.11 \mathrm{~kg} \cdot \mathrm{m}^{-2}\right)$. Mean AGB in the control group was $0.48 \mathrm{~kg} \cdot \mathrm{m}^{-2}$, which was about twofold AGB of the selective-cutting 1998 group $\left(0.22 \mathrm{~kg} \cdot \mathrm{m}^{-2}\right)$, and four-fold understory planting group (Fig. 1). Plants in the shrub (leaves and branches) and herb layers provide a major source of food for forest animals. Fresh weight could be used to estimate the environmental capacity of target species whose main habitat was forest. The mean value of the control group's fresh weight was about $2 \mathrm{~kg} \cdot \mathrm{m}^{-2}$, which was about two-fold the AGB of

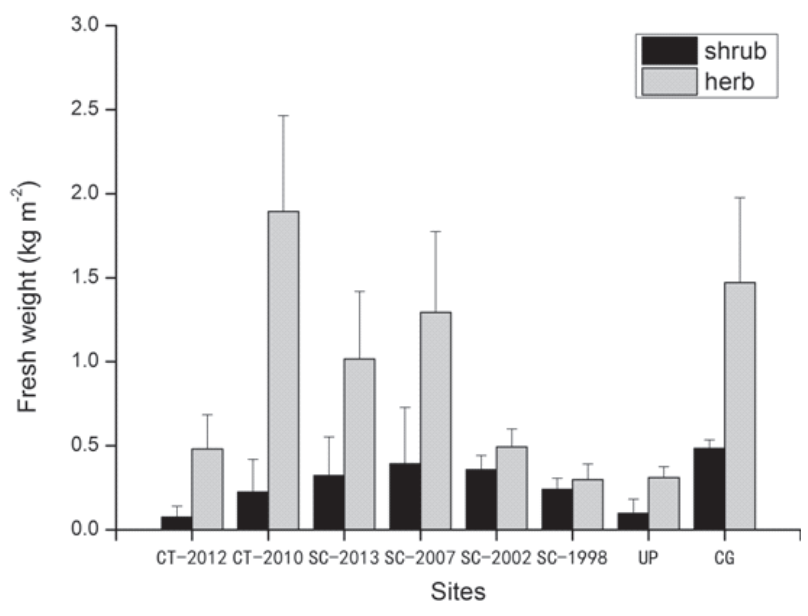

Fig. 1. Fresh weight $\left(\mathrm{kg} \cdot \mathrm{m}^{-2}\right)$ of the understory vegetation at different sites. CT, tending of cut shrubs; $\mathrm{SC}$, selective cutting; UP, understory planting; CG, control group without treatment; year of management is also indicated for ST and SC sites.

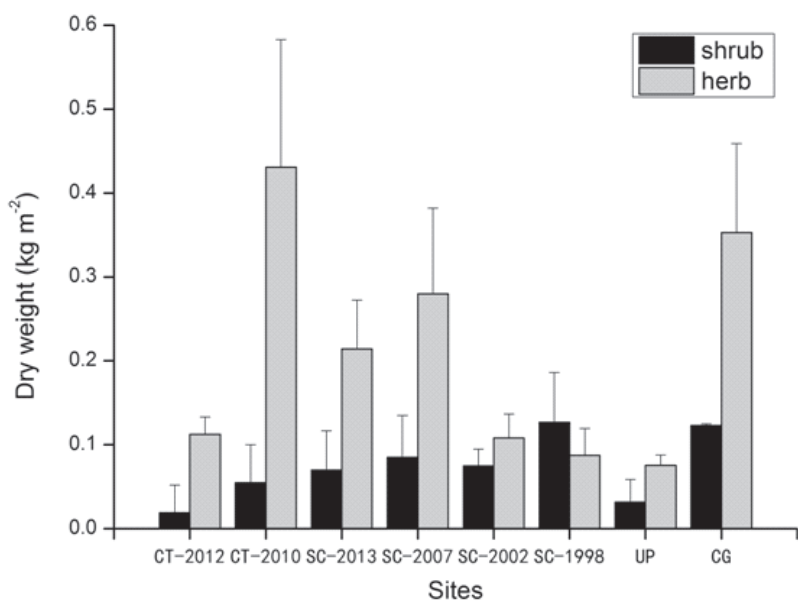

Fig. 2. Dry weight $\left(\mathrm{kg} \cdot \mathrm{m}^{-2}\right)$ of the understory vegetation at different sites. The plant surveys were performed between June and October 2013 at Tieli Forestry Bureau in northeastern China $\left(47^{\circ} 02^{\prime} 47^{\circ} 36^{\prime} \mathrm{N}, 127^{\circ} 57^{\prime} 128^{\circ} 12^{\prime} \mathrm{E}\right)$; see Fig. 1 for definitions of acronyms. the selective cutting group $\left(1 \mathrm{~kg} \cdot \mathrm{m}^{-2}\right)$ and five-fold the understory planting group $\left(0.4 \mathrm{~kg} \cdot \mathrm{m}^{-2} ; \mathrm{Fig}\right.$. 2).

\section{Richness and Species Diversity}

Table 5 provides plant species richness, and the Pielou, Berger-Parker and Shannon-Wiener indices. When we analyzed shrub and herb species richness, a significant difference $(p<0.05)$ was found among sites. The average herb species richness was higher than that of shrubs. The relatively small number of plant species richness and the infrequent occurrence of many of them resulted in relatively small diversity indices. SC-2007 recorded the lowest species richness and the mean species richness was nearly half in UP when compared with CG. Shannon's diversity indices $\left(H^{\prime}\right)$ indicate the decrease in diversity of plant communities after CT-2012, SC-2007, and UP. The dominance of SC-2007 in communities resulted in small values for Pielou's evenness index $(J)$ and Berger-Parker's dominance index $(D)$. When comparing management patterns in different sites, we found that the $J$ and $D$ indices were very stable for herbaceous species. Evenness for shrub species of SC-2007 tended to be the least after UP. Nevertheless, when diversity indices were considered comprehensively, SC-2013 and CG were the most diverse sites.

\section{Discussion}

\section{Vegetation Structure}

Planting of agarics is economically viable at sites with a low density understory, which may explain how planting in areas with intensive human activities may lead to poor species diversity. Explaining why the understory of nonmanagement has the highest average coverage is easy, because both human and animal activities may disturb understory plants, resulting in a decrease of coverage. The height and coverage of plants in the understory planting group were the lowest, which could be explained by the diverse management techniques used in the understory planting group such as weeding, fertilizing, pruning, and harvesting, etc., during the growing season.

\section{Biomass and Environmental Capacity}

Weeding, thinning, and cutting directly reduced the biomass of the understory [29]. The biomass of managed samples was less than that of the control group if the cut shrub-tending 2010 group was excluded. Herbs grew well with more light and more space after cut shrub tending. In the summer of 2013 the vegetation study showed that shrubs would re-grow over three years (from 2010 to 2013), resulting in the high biomass of the cut shrub-tending 2010 sample plots. In general, biomass is positively correlated to the capacity of the environment to support forest animals. The differences in AGB are not a good indication of the level of animal habitat protection 
Table 5. Floristic species diversity indices at different sites studied here.

\begin{tabular}{|c|c|c|c|c|c|c|c|c|}
\hline \multirow{2}{*}{ Sites } & \multicolumn{4}{|c|}{ Shrub species } & \multicolumn{4}{c|}{ Herb species } \\
\cline { 2 - 10 } & $S$ & $J$ & $H^{\prime}$ & $D$ & $S$ & $J$ & $H^{\prime}$ & $D$ \\
\hline CT-2012 & 7 & 0.68 & 1.32 & 0.65 & 9 & 0.79 & 1.74 & 0.75 \\
\hline CT-2010 & 10 & 0.8 & 1.84 & 0.78 & 8 & 0.68 & 1.41 & 0.68 \\
\hline SC-2013 & 9 & 0.86 & 1.89 & 0.82 & 11 & 0.86 & 2.07 & 0.86 \\
\hline SC-2007 & 3 & 0.57 & 0.62 & 0.33 & 7 & 0.71 & 1.38 & 0.69 \\
\hline SC-2002 & 5 & 0.9 & 1.45 & 0.75 & 10 & 0.76 & 1.75 & 0.77 \\
\hline SC-1998 & 6 & 0.9 & 1.46 & 0.75 & 8 & 0.69 & 1.43 & 0.67 \\
\hline UP & 3 & 0.59 & 0.65 & 0.35 & 8 & 0.93 & 1.93 & 0.85 \\
\hline CG & 8 & 0.79 & 1.64 & 0.75 & 17 & 0.75 & 2.03 & 0.84 \\
\hline
\end{tabular}

$S$, species richness; $J$, Pielou index of diversity; $H^{\prime}$, Shannon index; $D$, Berger-Parker index of dominance; see Table 2 for definitions of site acronyms.

because some management may result in habitat degradation and fragmentation, and a significant loss of carbon $[1,30]$. Starting in the 1990s, Atlanta (GA, United States) began to implement a forest protection policy that reduced the industrialized management of private forests; after 10 years, an evaluation of habitat [31] showed that wildlife (e.g., Martespennanti, Dryocopuspileatus, and Vireo gilvus) improved significantly [31]; however, this type of validation was needed over a long time scale. For example, in New England (northeastern United States), the aboveground biomass of public forests was 30 percentage points higher than that of private forests according to a study by Zheng et al. (2010), and we know that public forests employ relatively simple management patterns [32].

\section{Changes in Plant Biodiversity}

In this study, large differences in species richness and composition were observed within mixed forests with four types of understory management. We found the understory planting group had the lowest species richness and the control group exceeded all others, which was supported by Knapp et al. (2007) [33]. This may be explained by current management practices, specifically in understory planting sites where the understory was removed several times annually. This clearing was clearly not selective and eliminated most regeneration of all plant species; however, some species tended to escape elimination [34-35].

Foremost, when comparing the species richness indices of different sites, we found that the indices related to the selective-cutting 2013 group were close to the control group. Because the field surveys in summer occurred about half of a year after the selective cutting, we could not measure any obvious change in species richness caused by selective cutting. We also found that the species richness in selective-cutting 1998 and 2007 groups decreased significantly over time. In addition, we observed that the Pielou index in the control group was in the mid-range, which proved that management increased the nonuniformity of plant species distribution. When considering the Shannon and Berger-Parker indices in the understory planting group, the indices of the herb layer were higher and the shrub layer was lower than other areas, which indicated that the understory planting had a stronger influence on the shrub layer than the herb one. We concluded that as cutting continued over time and the intensity of human disturbance increased, such as more intense understory planting measures, the impact to herb and shrub biodiversity was great [36].

In addition, counting some species' numbers accurately proved to be difficult because of the large size of some herbaceous species and because some of the Gramineae species grew in clusters. We used importance value $p_{\mathrm{i}}$ to replace the index of each species number as the basis for calculating diversity indices in consideration of the height, coverage, and abundance of various species. We believe this method is more accurate and more persuasive.

\section{Implication}

Results of plant surveys and analysis of biological diversity clearly demonstrated that obvious differences can be quantified between management types in the understory of mixed forests. Management in a conservation area is important to biodiversity and structural diversity. Two conspicuous management types may be recognized within the mixed forest stands studied here: cut-shrubs tending and understory planting. The former creates the highest herbaceous biomass, moderate species richness, and low shade cover; and the latter results in low biomass, intermediate coverage, and high herbaceous species diversity (Table 5, Figs 1-2).

Some studies have found that management patterns have affected the structure of a forest landscape as well as its ecological characteristics, biodiversity, and habitat [37]. In particular, forest rights have become more dispersed among more local land managers and those rights have 
frequently circulated between different parties in recent years [27, 38-39]. In addition, more focus has been placed on changing the way forests are managed and addressing habitat fragmentation caused by the change of land use and forest ownership [40-43]. However, with the increase of forestry work intensity and frequency, this human pressure disturbed plant diversity and vegetation structure [27]. Development of the under-forestry economy has led to increasingly isolated large patches, which should be protected. Results from our study suggest that forest managers need to control human disturbance and protect the understory of mixed boreal forests in order to better preserve the biodiversity.

\section{Conclusions}

Results of this study demonstrate that management types in the understory of mixed forests may have negative effects on plant diversity and also affect vegetation structure and plant biomass. We can conclude that the effects of understory planting significantly affect the diversity and vegetation structure of understory species. Of definite importance is planting management near roads; therefore, simple measures such as vegetation coverage on both sides of roads should be increased. We recommended that people choose both the right time and the right path when working in forests by avoiding suitable habitat while attempting to minimize their level of disturbance by avoiding disturbances, if possible. We hope to solve the conflict between the need for small-scale human management and large-scale habitat conservation by conducting a more in-depth study in the future.

\section{Acknowledgements}

We thank all the members of the landscape ecology group for assistance in fieldwork. This study was funded by and conducted under the auspices of the National Natural Science Foundation of China (Nos. 41271201, 41371198, 41201185).

\section{References}

1. HERVE B., BISSELEUA D., VIDAL S. Plant biodiversity and vegetation structure in traditional cocoa forest gardens in southern Cameroon under different management. Biodivers. Conserv. 17, 1821, 2008.

2. BERGERON Y. Species and stand dynamics in the mixed woods of Quebec's southern boreal forest. Ecology. 81, $1500,2000$.

3. BRASSARD B.W., CHEN H.Y.H., WANG J.R., DUINKER P.N. Effects of time since stand-replacing fire and overstory composition on live-tree structural diversity in the boreal forest of central Canada. Can. J. For. Res-Rev. Can. Rech. For. 38, 52, 2008.

4. WALLRUP E., SAETRE P., RYDIN H. Deciduous trees affect small-scale floristic diversity and tree regeneration in conifer forests. Scand. J. Forest Res. 21, 399, 2006.
5. HART S.A., CHEN H.Y.H. Understory vegetation dynamics of North American boreal forests. Crit. Rev. Plant Sci. 25, $381,2006$.

6. QIAN H., KLINKA K., OKLAND R.H., KRESTOV P., KAYAHARA G.J. Understorey vegetation in boreal Picea mariana and Populus tremuloides stands in British Columbia. J. Veg. Sci. 14, 173, 2003.

7. YANG J., KONG J., LIU B. A review of effects of fire disturbance on understory vegetation in boreal coniferous forest. Acta Phytoecologica Sinica. 37, 474, 2013.

8. NILSSON M.C., WARDLE D.A. Understory vegetation as a forest ecosystem driver: evidence from the northern Swedish boreal forest. Front. Ecol. Environ. 3, 421, 2005.

9. BURRASCANO S., SABATINI F.M., BLASI C. Testing indicators of sustainable forest management on understorey composition and diversity in southern Italy through variation partitioning. Plant Ecol. 212, 829, 2011.

10. NAGAIKE T., KAMITANI T., NAKASHIZUKA T. Effects of different forest management systems on plant species diversity in a Fagus crenata forested landscape of central Japan. Can. J. For. Res-Rev. Can Rech. For. 35, 2832, 2005.

11. TIMILSINA N., ROSS M.S., HEINEN J.T. A community analysis of sal (Shorea robusta) forests in the western Terai of Nepal. For. Ecol. Manag. 241, 223, 2007.

12. AUBERT M., ALARD D., BUREAU F. Diversity of plant assemblages in managed temperate forests: a case study in Normandy (France). For. Ecol. Manag. 175, 321, 2003.

13. METLEN K.L., FIEDLER C.E. Restoration treatment effects on the understory of ponderosa pine/Douglas-fir forests in western Montana, USA. For. Ecol. Manag. 222, 355, 2006.

14. OHMANN J.L., GREGORY M.J., SPIES T.A. Influence of environment, disturbance, and ownership on forest vegetation of Coastal Oregon. Ecol. Appl. 17, 18, 2007.

15. WU Z.W., HE H.S., BOBRYK C.W., Liang Y. Scale effects of vegetation and topography on burn severity under prevailing fire weather conditions in boreal forest landscapes of Northeastern China. Scand. J. Forest Res. 29, 60, 2014.

16. BOBO K.S., WALTERT M., SAINGE N.M., NJOKAGBOR J., FERMON H., MUEHLENBERG, M. From forest to farmland: Species richness patterns of trees and understorey plants along a gradient of forest conversion in southwestern Cameroon. Biodivers. Conserv. 15, 4097, 2006.

17. LENCINAS M.V., PASTUR G.M., GALLO E., CELLINI J.M. Alternative silvicultural practices with variable retention to improve understory plant diversity conservation in southern Patagonian forests. For. Ecol. Manag. 262, 1236, 2011.

18. KELES S., BASKENT E.Z. Modelling and analyzing timber production and carbon sequestration values of forest ecosystems: a case study. Pol. J. Environ. Stud. 16, 473, 2007.

19. CHABRERIE O., LOINARD J., PERRIN S., SAGUEZ R., DECOCQ G. Impact of Prunus serotina invasion on understory functional diversity in a European temperate forest. Biol. Invasions. 12, 1891, 2010.

20. GAO P., KUPFER J.A., GUO D., LEI T.L. Identifying functionally connected habitat compartments with a novel regionalization technique. Landsc. Ecol. 28, 1949, 2013.

21. LECLERC M., DUSSAULT C., ST-LAURENT M.H. Multiscale assessment of the impacts of roads and cutovers on calving site selection in woodland caribou. For. Ecol. Manag. 286, 59, 2012.

22. SONNIER G., JAMONEAU A., DECOCQ G. Evidence for a direct negative effect of habitat fragmentation on forest herb functional diversity. Landsc. Ecol. 29, 857, 2014. 
23. GILLIAM F.S. The ecological significance of the herbaceous layer in temperate forest ecosystems. Bioscience. 57, 845, 2007.

24. KERNS B.K., THIES W.G., NIWA C.G. Season and severity of prescribed burn in ponderosa pine forests: Implications for understory native and exotic plants. Ecoscience. 13, 44, 2006.

25. TAI S.S., HU Y.M., ZHANG H.S., HAN Y.K., WU D.F. Effects of planting mode in forest on understory plant species diversity in mountain area of Eastern Liaoning Province in the reform of collective forest property. J. Appl. Ecol. 29, 238, 2010.

26. TANG Q., LIANG G.F., LU X.L., DING S.Y. Effects of corridor networks on plant species composition and diversity in an intensive agriculture landscape. Chinese Geogr. Sci. 24, 93, 2014.

27. LI Y., WU W., LI N., BU R., HU Y. Effects of forest ownership regime on landscape pattern and animal habitat: A review. The Journal of Applied Ecology. 24, 2056, 2013.

28. DRAMSTAD W.E., FJELLSTAD W.J. Twenty-five years into "our common future": are we heading in the right direction? Landsc. Ecol. 28, 1039, 2013.

29. WEIGELT A., SCHUMACHER J., ROSCHER C., SCHMID B. Does biodiversity increase spatial stability in plant community biomass? Ecol. Lett. 11, 338, 2008.

30. PIEKIELEK N.B., HANSEN A.J. Extent of fragmentation of coarse-scale habitats in and around US National Parks. Biol. Conserv. 155, 13, 2012.

31. VIEIRA M.V., OLIFIERS N., DELCIELLOS A.C., ANTUNES V.Z., BERNARDO L.R. Land use vs. fragment size and isolation as determinants of small mammal composition and richness in Atlantic Forest remnants. Biol. Conserv. 142, 1191, 2009.

32. ZHENG D.L., HEATH L.S., DUCEY M.J., BUTLER B. Relationships Between Major Ownerships, Forest Aboveground Biomass Distributions, and Landscape Dynamics in the New England Region of USA. Environ. Manage. 45, 377, 2010.

33. KNAPP E.E., SCHWILK D.W., KANE J.M., KEELEY J.E. Role of burning season on initial understory vegetation response to prescribed fire in a mixed conifer forest. Can. J. For. Res-Rev. Can. Rech. For. 37, 11, 2007.

34. FAHEY R.T., PUETTMANN K.J. Patterns in spatial extent of gap influence on understory plant communities. For. Ecol. Manag. 255, 2801, 2008.

35. MUSCOLO A., SIDARI M., MERCURIO R. Influence of gap size on organic matter decomposition, microbial biomass and nutrient cycle in Calabrian pine (Pinus laricio, Poiret) stands. For. Ecol. Manage. 242, 412, 2007.

36. SCHULZE C.H., WALTERT M., KESSLER P.J.A., PITOPANG R., SHAHABUDDIN. Biodiversity indicator groups of tropical land-use systems: Comparing plants, birds, and insects. Ecol. Appl. 14, 1321, 2004.

37. BONNOT N., MORELLET N., VERHEYDEN H., CARGNELUTTI B., LOURTET B. Habitat use under predation risk: hunting, roads and human dwellings influence the spatial behaviour of roe deer. Eur. J. Wildl. Res. 59, 185, 2013.

38. NAGENDRA H., PAREETH S., SHARMA B., SCHWEIK C.M., ADHIKARI K.R. Forest fragmentation and regrowth in an institutional mosaic of community, government and private ownership in Nepal. Landsc. Ecol. 23, 41, 2008.

39. SIRY J., CUBBAGE F., NEWMAN D., IZLAR R. Forest ownership and management outcomes in the US, in global context. Int. For. Rev. 12, 38, 2010.

40. GUSTAFSON E.J., LYTLE D.E., SWATY R., LOEHLE C. Simulating the cumulative effects of multiple forest management strategies on landscape measures of forest sustainability. Landsc. Ecol. 22, 141, 2007.

41. HOLMGREN L., HOLMGREN E., FRIDMAN J., LIDESTAV G. Biological diversity indicators: A comparison of Swedish forest commons and other forest ownership categories. Scand. J. of Forest Res. 25, 61, 2010.

42. KO D.W., HE H.S., LARSEN D.R. Simulating private land ownership fragmentation in the Missouri Ozarks, USA. Landsc. Ecol. 21, 671, 2006.

43. TURNER M.G., WEAR D.N., FLAMM R.O. Land ownership and land-cover change in the southern Appalachian highlands and the Olympic peninsula. Ecol. Appl. 6, 1150, 1996. 